\title{
PERANAN CYBERSPACE SEBAGAI PEMBENTUK AKTIVISME POLITIK INTERNET DI INDONESIA
}

\author{
Abdul Gofur \\ Program Studi Pendidikan Pancasila dan Kewarganegaraan \\ Program Pascasarjana Universitas Negeri Yogyakarta
}

Gofurabdu1319@gmail.com

\begin{abstract}
ABSTRAK
Perkembangan ilmu pengetahuan dan teknologi (IPTEK) memberikan dampak perubahan cara pandang maupun aktivitas warganegara dalam berkomunikasi. Fenomena Cyberspace atau yang disebut dengan dunia maya tentu berakibat pada penyempitkan, ruang, waktu, dan jarak sehingga saling terkoneksi satu sama lainnya. Tulisan ini bertujuan untuk memperdalam dan menambah wawasan mengenai Peranan Cyberspace Sebagai Pembentuk Aktivisme Politik Internet di Indonesia.

Metode yang digunakan dalam penulisan karya ilmiah ini adalah library research atau studi keputakaan dengan mendasarkan beberapa referensi yang terkait. Dengan demikian akan memperkaya mengenai konsep Peranan Cyberspace Sebagai Pembentuk Aktivisme Politik Internet di Indonesia

Hasil penelitian menunjukkan semakin meningkatnya pengguna internet di Indonesia perlu dimanfaatkan sebagai wadah dalam menyuarakan kepentinga, krtik serta menjadi ruang diskusi publik. Dalam posisi sebagai warganegara aktivisme politik internet perlu di posisikan sebagai demos untuk penyeimbang dan pengawas Negara. Pada ranah demokrasi, pemanfaatan teknologi internet untuk gerakan masyarakat sipil menjadi sebuah solusi. Penetrasi oleh pengguna media sosial pada ruang cyberspace mampu mendorong adanya deliberasi nilai-nilai demokrasi seperti halnya kesukarelaan (voluntarism), kesamaan (egalitarianism), maupun juga berjejaring (networking) dalam kondisi demokrasi kontemporer.
\end{abstract}

Kata kunci: Cyberspace; Aktivisme Politik, Demokrasi

\section{ABSTRACT}

The development of science and technology gives the impact in the change of perspective and activities of citizens in communicating. Cyberspace phenomenon or called the virtual world would result in narrowing space, time, and distance so that they are connected to each other. Increasingly internet users in Indonesia need to be utilized as a container in expressing interests, critics, and be a public discussion space.As citizens,

Internet political activism needs to be positioned as a demos for countervailing and supervising the state. In democracy aspect, the utilization of internet technology becomes a solution for civil society movement. Penetration by social media users in the cyberspace is able to encourage the deliberation of democratic values such as voluntarism, egalitarianism, or networking in contemporary democratic conditions. This paper aims to deepen and add insight about the role of Cyberspace as the form of Internet Political Activism in Indonesia.

The method of this research is library research by collecting some related references. Thus, it will improve the knowledge about the role of Cyberspace as the form of internet political astivism in Indonesia.

Keywords: Cyberspace, Political Activism, Democracy 


\section{A. PENDAHULUAN}

Perkembangan ilmu pengetahuan dan teknologi (IPTEK) memberikan dampak terhadap kehidupan manusia, baik dari segi cara pandang maupaun aktivitas. Teknologi informasi dan komunikasi terutama Internet yang di dalamnya terdapat ribuan jaringan komputer dan database, telah menciptakan ruang tanpa batas sehingga berakibat pada penyempitkan, ruang, waktu, dan jarak sehingga saling terkoneksi satu sama lainnya. Besarnya pengguna internet, terutama aktivitas di jejaring media sosial, berakibat langsung terhadap meningkatnya rasionalitas dalam berpolitik. Sebagaimana Hasil survei Pusat Penelitian Politik LIPI terhadap indeks persepsi politik menyebutkan, hampir $70 \%$ pengetahuan politik diperoleh dari aktivitas media sosial. Artinya, penggunaan media sosial berkembang menjadi ruang deliberatif yang intens membincangkan isu-isu dan dinamika politik keseharian. Publik mendapatkan banyak saluran tidak hanya melalui pers sebagai media mainstream, tetapi juga melalui konten internet dan media sosial. Banyaknya jumlah penduduk yang aktif pada Cyberspace (dunia maya) perlu dimanfaatkan sebagai wadah dalam menyuarakan kepentinga, krtik serta menjadi ruang diskusi publik. Berbagai macam isu dan tema yang diperbincangkan dari berbagai sumber memicu adanya kesadaran kritis publik dalam menilai dan memandang suatu peristiwa tertentu. Implikasinya yang ditimbulkan kemudian adalah munculnya warganegara yang melek secara politik

Ruang publik maya dapat digunakan oleh warganegara dalam rangka mengembangkan dirinya secara maksimal dalam segala aspek kehidupan, termasuk di dalamnya bidang ekonomi, hukum, humaniora, hiburan, dan politik atau bidang lainnya. Gaffar (2006: 183). Dalam ruang tersebut, semua orang lintas benua dan lintas negara kemudian bisa saling berdiskusi dan berinteraksi satu sama lainnya. Dengan kata lain, keberadaan internet telah banyak membantu adanya proses pendalaman demokrasi (democracy deepening) dalam masyarakat.

Perkembangan demokrasi di Indonesia tengah mengalami pergeseran pada arena demokrasi digital dengan menggabungkan konsep demokrasi perwakilan dan demokrasi partisipatif sehingga mampu mengeksplorasi dengan cepat antara dunia 
maya dan sosial. Model demokrasi digital dapat didefiniskan sebagai pemanfaatan teknologi komunikasi guna memajukan partisipasi masyarakat dalam berdemokrasi. Melalui internet, masyarakat dimungkinkan untuk melakukan berbagai eksperimen dan inovasi desain komunikasi ketika dihadapkan dengan wakil-wakil politik mereka terkait kebijakan yang dijalankan (Bell, 2004: 58).

Penetrasi internet melalui cyberspace adanya deliberasi nilai-nilai demokrasi seperti halnya kesukarelaan (voluntarism), kesamaan (egalitarian), maupun juga praktik berjejaring (networking) menyebar dan diterima secara meluas dalam masyarakat. Dengan demikian Masyarakat akan dengan mudah dan cepat dapat membentuk peer group berdasarkan kesamaan minat maupun isu spesifik tertentu. Selain itu juga, suara minoritas yang selama ini termarjinalkan dalam praktik majoritarian pada sistem demokrasi kovensional, mendapatkan tempat untuk mengartikulasikan kepentingan dan identitasnya. Adanya ruang yang dinamis dan heterogen itulah yang membuat publik ramai menjadi netizen secara aktif maupun pasif dalam cyberspace. Tujuuan dari penulisan ini adalah untuk memberikan

pengetahuan serta wawasan yang lebih mendalam mengenali peranan cyberspace sebagai pembentuk aktivisme politik internet di indonesia.

\section{B. METODE PENELITIAN}

Metode penulisan ini menggunakan metode library research. Metode ini merupakan salah satu jenis metode penelitian kualitatif. Riset pustaka ini membatasi hanya pada bahan-bahan koleksi perpustakaan, tanpa memerlukan riset lapangan. Metode ini digunakan untuk menjawab studi pendahuluan (prelinmary research) untuk memahami lebih mendalam gejala baru yang tengah berkembang di lapangan atau dalam masyarakat (Mustika Zed, 2004). Selanjutnya, menurut Mestika Zed (2004:54), menjelaskan bahwa riset kepustakaan adalah serangkaian kegiatan yang berkenaan metode pengumpulan data pustaka, membaca dan mencatat serta mengolah bahan penelitian. Sumber dan jenis data yang digunakan dalam penyusunan karya tulis ini yaitu berasal dari berbagai literatur kepustakaan yang berkaitan dengan tema yang dibahas. 
Hal tersebut, didasarkan dengan teknik pengumpulan data, yaitu studi kepustakaan. Beberapa jenis literatur utama yang digunakan terdiri atas, Sedangkan, teknik pengumpulan data dilakukan dengan library research, yaitu mengidentifikasi berbagai referensi yang terkait dengan judul karya tulis. Data atau informasi tersebut, didapatkan dari literatur yang dapat dipertanggungjawabkan, selanjutnya disusun berdasarkan hasil studi, sehingga terkait satu sama lain dan sesuai dengan tema yang dibahas.

Analisis data dilakukan secara induktif, yang di dalamnya terdiri dari dua tahap yaitu proses reduksi data dan penyajian data. Reduksi data bertujuan untuk penulis lebih mudah dalam memilih data yang valid, sedangkan penyajian data agar dimungkinkan penarikan simpulan. Penyajian data yaitu pengumpulan informasi yang tersusun dan memberi kemungkinan adanya penarikan simpulan, maupun pengambilan suatu tindakan tertentu. Penyajian data merupakan analisis dalam bentuk teori dan argumentatif sehingga penulis dapat dengan menguasai dengan baik.

Penarikan simpulan didapatkan sesudah merujuk tujuan penulisan, analisis dan sintesis. Simpulan juga memperhatikan penyajian data dari pembahasan yang ditarik merepresentasikam pokok-pokok bahasan dalam karya tulis serta didukung dengan saran praktis sebagai rekomendasi selanjutnya.

\section{HASIL PENELITIAN DAN PEMBAHASAN}

\section{Konsep Cyberspace}

Cyberspace berkaitan erat dengan media berupa jaringan komputer digital dimana komunikasi antar entitas (baik yang berwujud manusia maupun yang bukan manusia) berlangsung. Dalam perkembangannya, istilah cyberspace" kemudian dipahami tidak sekedar sebagai jaringan dalam aspek teknis, tetapi lebih luas membicarakan mengenai interaksi sosial. Bagaimana media komputasi digital merupakan ekstensi dari saluran komunikasi (meliputi manusia dan sistem yang saling berinteraksi) yang merupakan simulasi dari dunia nyata dengan kemampuan saling mempengaruhi dengan motif yang beragam seperti informasi, ekonomi, politik, dan sebagainya. (Tomic, 2004: 29). 
Salah satu fenomena menarik dalam perkembangan teknologi komunikasi adalah adanya internet yang memberi kemudahan bagi setiap pengguna untuk berhubungan dalam jangka waktu yang cepat, mudah dan massif. Di dalam ruang publik, Internet dapat di gunakan sebagai sarana menyampaikan ide dan menduskusikan isu-isu yang sedang menjadi topik yang diperbincangkan oleh publik, maupun berupa sebuah kritik kebijakan pemerintah, tanpa dibatasi oleh jarak, ruang, dan waktu.

Tentu dengan semakin menguatnya penetrasi internet dalam ruang sosial politik terutama pada kelas menengah Indonesia semakin masif dalam beberapa tahun takhir. Menurut hasil penelitian yang dilakukan oleh Pusat Penelitian Politik LIPI Tercatat pengguna internet di Indonesia kini mencapai 72 juta netizen aktif. Asosiasi Penyelenggara Jasa Internet Indonesia (APJII) memaparkan persentase aktivasi internet tersebut yaitu sosialisasi (71\%), informasi (65,3\%), mengikuti perkembangan zaman $(51,2 \%)$, dan bersenang-senang (32,6\%). Media sosial menempati fitur teratas dalam aktivasi internet di Indonesia dengan menempatkan aplikasi Facebook (14\%), WhatsApp (12\%), dan Twitter (11\%), sebagai tiga model sosial media teratas dan sebagian besar merupakan kelas menengah Indonesia. Fakta ini jelas membuktikan bahwa animo dan ketergantungan warganegara terutama kelas menengah terhadap internet semakin meninggi.

Hal ini sejalan dengan temuan bahwa banyaknya fitur media sosial yang diakses netizen tersebut menujukkan adanya gejala over-connected. Gejala tersebut menunjukkan adanya intensitas tinggi untuk saling berkomunikasi dan bersosialisasi satu sama lainnya berdasarkan kesamaan tema, isu, maupun kepentingan. Adanya komunikasi lewat sosial media yang saling berjejaring tersebut menghasilkan kesukarelaan (voluntarism), kesamaan (egalitarian), maupun juga praktik berjejaring (networking) menyebar dan diterima secara meluas dalam masyarakat. Pengertian masyarakat berjejaring tersebut terbentuknya ikatan kewarganegaraan online berdasarkan pada kesamaan minat isu dan topik. Perkembangan globalisasi mutakhir menempatkan bahwa saluran komunikasi, publik, maupun juga agen advokasi 
kebijakan tidak lagi berada dalam ranah lingkup nasional, namun juga merambah ranah internasional (Jati, 2016: 29)

\section{Aktivisme Internet di Indonesia}

Tantangan bangsa Indonesia terhadap cyberspace adalah aktivisme online yang terjadi dapat termanifestasikan ke dalam gerakan poiitik yang nyata dalam ruang publik. Seyogyanya ruang media sosial dapat digunakan sebagai ruang produktif. Aktivisme online merupakan bagian dari praktik politik digital dalam masyarakat. Adapun pengertian digital politik memiliki pengertian multiintepretatif, namun demikian kristalisasi dari berbagai macam konsep tersebut kemudian merujuk pada terbentuknya ruang publik dalam dunia maya (cyberspace) (Postill, 2012). Ruang tersebut dapat dikatakan sebagai ruang non struktural, dinamis, egaliter yang memungkinkan setiap orang dapat berpartisipasi melalui jaringan online.

Pemerintah telah mengatur kebebasan didalam penggunaan media online. Sebagaimana UU ITE tahun 2008 yang disahkan oleh Pemerintah untuk mengatur informasi dan jasa elektronik berbasis online. Poin-poin krusial dalam UU ITE tersebut terletak pada pasal 27 ayat 1 dan 3, pasal 28 ayat 2, dan pasal 31 ayat 3 yang mengatur kebebasan berpartisipasi dalam penggunaan media online. Namun Undangundang tersebut seringkali menyasar kepada pengguna yang aktif melakukan kritik terhadap rezim penguasa.

Partisipasi di dunia maya inilah yang kemudian menciptakan terciptanya "warga digital" (digital citizenship), yang oleh Karen Mossberger (2008: 5) didefinisikan sebagai kemampuan untuk berpartisipasi dalam masyarakat online. Secara lebih luas dapat juga dikatakan bahwa "warga digital" mereka yang sering menggunakan teknologi, yang menggunakan teknologi untuk informasi politik untuk memenuhi kewajiban mereka sebagai warga negara, dan yang menggunakan teknologi di tempat kerja untuk keuntungan ekonomi. Dengan demikian apa yang disebut partisipasi politik online mencakup diskusi politik melalui email grup, dan posting komentar di Blog. sebagaimana dikatakan Homero Gil de Zúñig, (2010: 38), internet juga dapat membawa elit politik dan masyarakat lebih dekat bersama-sama, sehingga lebih 
mudah untuk mengekspresikan pandangan kepada para pejabat terpilih maupun kepada jurnalis. Dengan kemudahan-kemudahan tersebut setiap warga bisa dengan mudah untuk terlibat aktif dalam partisipasi online, mengirim e-mail ke seorang politikus ataupun menandatangani petisi online, dengan harapan bahwa pesan-pesan politik mereka akan sampai untuk bisa merubah keputusan-keputusan yang terkait dengan kebijakan publik.

Peran sebagai netizen yang mampu menciptakan gerakan masa dan mampu menampilkan dirinya sebagai demos untuk penyeimbang dan pengawas negara. Berbagai gerakan politik mutakhir beberapa wktu silam misalnya, dari kasus Komisi Pemberantasan Korupsi (KPK) vs Polri pada 2009-2010 hingga relawan pada Pemilu 2014 sebagai kekuatan partisan publik untuk mendukung Jokowi sebagai Presiden, kekuatan partisan pada tahun 2014 silam merupakan titik krusial bagi suksesi kekuasaan Indonesia dimana terdapat kebutuhan untuk mengakhiri elitisme dan oligarki kekuasaan dengan kebutuhan adanya figur populisme untuk mengakhiri oligarki kekuasaan. Hal ini menunjukkan bahwa kekuatan politik media sosial merupakan kekuatan potensial dalam lanskap politik Indonesia. Dorongan kelas menengah yang secara intens dan instan dalam mengakses media sosial merupakan elemen penting gerakan politik tersebut. Apalagi, kelas menengah Indonesia kini didominasi kalangan profesional (55\%), mahasiswa (18\%), dan ibu rumah tangga (16\%) merupakan aktor penting yang membuat gerakan politik tersebut berlangsung secara masif dan dinamis.

\section{Demokrasi Digital}

Peningkatan kapasitas internet sebagai bagian dari kepentingan publik juga berakibat pada perkembangan demokrasi Indonesia kini tengah mengarah kepada Demokrasi digital, dimana partisipasi wargenagara tidak hanya dapat disampaikan lewat ruang publik secara nyata namun dapat disampaikan pada ruang maya atau cyberspace. Secara harfiah pengertian demokrasi digital dapat dipahami sebagai implementasi demokrasi yang tidak terkungkung pada limitasi ruang, waktu, ataupun batasan fisik lainnya. Demokrasi digital menggabungkan konsep demokrasi perwakilan dan demokrasi partisipatif sehingga mampu mengeksplorasi dengan cepat 
interaksi antara dunia maya dan sosial (Andriadi, 2016:149-150). Selanjutnya Model demokrasi juga disebut sebagai demokrasi digital yang didefiniskan sebagai pemanfaatan teknologi komunikasi guna memajukan partisipasi masyarakat dalam berdemokrasi. Melalui internet, masyarakat dimungkinkan untuk melakukan berbagai eksperimen dan inovasi desain komunikasi ketika dihadapkan dengan wakil-wakil politik mereka terkait kebijakan yang dijalankan (Bell, 2004: 58).

Secara teoretis dan praktis demokrasi digital menjelaskan bagaimana ICT (Information and Communication Technology) mempengaruhi demokrasi dan proses politik yang sedang berjalan. ICT saat ini memainkan peranan yang signifikan dalam pencapaian demokrasi yang kuat berdasarkan jaringan komunitas. Sejumlah ahli yakin bahwa ICT merupakan faktor yang potensial untuk mendorong perkembangan demokrasi, dan memfasilitasi sebuah lompatan kuantum dalam konteks demokrasi politik (Becker, 1998: 343).

Adanya sentuhan teknologi telah mengakselerasi demokrasi agar lebih dekat, nyata, dan berkontribusi penting dalam menciptakan demos secara kritis. Para netizen dapat tampil berperan sebagai demos dalam situasi kekinian melalui aktivitas, posting, dan sharing di akun media sosial masing-masing. Hal itulah yang menciptakan "nilai kedua" demokrasi digital, yakni demokrasi konektif, yaitu demokrasi yang sifatnya, berjejaring dari pada nilai demokrasi sebelumnya lebih bersifat kolektif, yakni lebih bersifat organik.

Secara garis besar, pembahasan demokrasi digital terbagi atas beberapa kata kunci, seperti relasi dunia maya (online) dan dunia nyata (offline), representasi dan partisipasi, serta netizen dapat di bagi menjadi dua yaitu,

1. Relasi dunia maya (online) dan dunia nyata (off line) berperan penting dalam konstruksi nalar politik kritis publik yang berusaha dan berlomba membentuk jejaring berdasarkan pada isu dan kepentingan yang sama untuk membentuk adanya gerakan.

2. Representasi dan partisipasi adalah prinsip demokrasi digital hari ini yang pada intinya meminta adanya keterbukaan dan aksesibilitas publik terhadap pemerintahan. 
3. Netizen adalah publik sebagai user ataupun receiver terhadap beragam informasi tersebut melalui akun media sosial masing-masing. (Andriadi, 2016: 122).

Pada akhirnya, demokrasi digital menciptakan adanya imajinasi-imajinasi politik dan demokrasi ideal menurut warga negara yang dirumuskan melalui ruangruang siber (cyberspace) sebagai ruang publik baru. Melekatnya fungsi media sosial dengan publik terhadap isu politik dikarenakan internet menciptakan adanya sensasi meruang (sense of space), sensasi menyata (sense of real), ataupun juga sensasi kebersamaan (sense of belonging).

\section{KESIMPULAN}

Perkembangan ilmu pengetahuan dan teknologi (IPTEK) memberikan dampak terhadap kehidupan manusia, baik dari segi cara pandang maupaun aktivitas. Dalam perkembangannya, istilah cyberspace" kemudian dipahami tidak sekedar sebagai jaringan dalam aspek teknis, tetapi lebih luas membicarakan mengenai interaksi sosial. Di dalam ruang publik, Internet dapat di gunakan sebagai sarana menyampaikan ide dan menduskusikan isu-isu yang sedang menjadi topik yang diperbincangkan oleh publik, maupun berupa sebuah kritik kebijakan pemerintah, tanpa dibatasi oleh jarak, ruang, dan waktu. Sebagaimana kasus Komisi Pemberantasan Korupsi (KPK) vs Polri pada 2009-2010 hingga relawan pada Pemilu 2014.

UU ITE tahun 2008 yang disahkan oleh Pemerintah untuk mengatur informasi dan jasa elektronik berbasis online Namun Undang-undang tersebut seringkali menyasar kepada pengguna yang aktif melakukan kritik terhadap rezim penguasa. Namun demikian Partisipasi di dunia maya inilah yang kemudian menciptakan terciptanya "warga digital" (digital citizenship). Melalui peningkatan kapasitas internet

partisipasi wargenagara tidak hanya dapat disampaikan lewat ruang publik secara nyata namun dapat disampaikan pada ruang maya atau cyberspace. Pada akhirnya, demokrasi digital menciptakan adanya imajinasi-imajinasi politik dan demokrasi ideal menurut warga negara yang dirumuskan melalui ruang-ruang siber (cyberspace) sebagai ruang publik baru. 


\section{DAFTAR PUSTAKA}

Andriadi, F. (2016). Demokrasi di Tangan Netizen:Tantangan dan Prospek Demokrasi Digital. Jakarta: RMBOOKS.

APJI and Puskakom - UI. (2015). Profil Pengguna Internet Indonesia 2014. Jakarta: APJII Press..

Becker, T. (1998). Governance and electronic innovation: A clash of paradigms. Information, Communication and Society Vol. 1, No.3, hal. 339-343.

Bell, L. P. (2004). Cyberculture The Key Concepts. London: Routladge.

Gaffar, A. (2006). Politik Indonesia: Transisi Menuju Demokrasi. Yogyakarta: Pustaka Pelajar.

Jati, W. R. (2016). Cyberspace, Internet, Dan Ruang Publik Baru: Aktivisme. Pemikiran Sosiologi, pp 25-35.

Mossberger. K (2008). Digital Citizenship: The Internet, Society, and Participation. London : The MIT Press

Postill, J. (2012). Digital Politics and Political Engagement. Edited H. Horst and D.Miller. Oxford: Berg

Tomic, A. L. (2004). Computer Mediated Communication Social Interaction And The Internet. California: Sage Publication.

Zed, M. (2004). Metode Penelitian Kepustakaan. Jakarta: PT Raja Grafindo Persada

Zúñiga, H. (2010). Digital Democracy: Reimagining Pathways to Political Participation. Journal of Information Technology \& Politics, 7:36-51, 2010 